TEE DEPOSITIONS OF 1641 .

I As unable to find any proof in those documents to sustain the assertion that the deponents were inspired by the 'intensest hatred ' of the Irish. On the contrary, they were ready to tell the good as well as the bad deeds done by the latter, vide 'Irish Massacres,' vol. i. pp. 178, 193, 198, 213, 308, and rol ii. pp. 50, 85. As regards my estimate of the numbers killed out of war, the reason of which Mr. Donlop desires to know, I gave it at page 162 of $\mathrm{my}$ 'Introduction.' Mr. Danlop is slike mistaken in supposing that ' I asked ' Mr. Froude to write the preface to my work; and that I said I did not 'know' his opinions about the msssscres. I 'knew' them, but I did not undertake to repeat what he has over and over again said on the sabject, needless to say, with far greater ability than I could bring to bear on it. I am unable to agree with him in all his opinions abont my native country, but I have a sincere respect for him, and admiration for his genius. I must, however, be permitted most distinctly to deny that I ever asked Mr. Froude to write a preface for my work, as Mr. Dunlop asserts that I did. Mr. Froude offered, rather to my surprise, to write the preface, and I very thankfolly accepted his kind offer, on condition that there was to be nothing in it which seemed to connect the volume with present politice.

I must still maintain that it pas mainly in consequence of the facts sworn to in those depositions, facts of rebellion, wholessle murder and spoliation, that three-fourths of the soil of Ireland changed hands in 1649-54; that immense numbers of Irish and Anglo-Irish were hanged, or banished or transplanted; and that therefore it is impossible to deny the high historical value of those documents, used in successive conts of justice, repablican or royalist, between 1649-70, in as many saccessive settlements of Ireland, the last of which is, as yet, virtually intact.

MARY Hroksos.

\title{
THE FORGED COMMISSION OF 1641 .
}

How far Charles I was goilty of instigating the Irish rebellion of 1641 is a question not essily and perhaps never to be completely and satisfactorily answered. It is generally admitted that in the summer of that year he, or his consort Henrietta, entered into negotiations with certain of the Irigh nobility through the medinm of the earl of Antrim. The object of these negotiations was to incite the nobles of the Pale to seize the chief fortresses for the ling, and to depose the lords justices Parsons and Borlase, who as nominees of the English parliament might naturally be expected to oppose the scheme. For it was Charles's intention to employ the army collected by the late earl of Strafford againat the parliament, and to this end it was necessary that Dublin as a sort of point d'appui should first of all be captured. This seems clear from the earl of Antrim's deposition delivered to the parliamentary commissioners after the conclusion of the war, and printed by $\mathrm{Cor}$ in his 'Hibernis Anglicana' (appendix rlix): "The late king, before the said rising of the Lrish in 
Ireland, sent one Thomas Bourk, hinsman to the earl of Clanricard, to the earl of Ormond and to the lord of Antrim with a message that it was the king's pleasure and command that those 8,000 men raised by the earl of Strafford in Ireland should be continued withont disbanding, and that they should be made ap to 20,000 , and that they should be armed out of the store of Dublin, and employed against the parliament, and particulariy that the castle of Dublin should be surprised and secured.' This command, however, arrived too late to be put into execution, for by that time the $8,000 \mathrm{men}$ had been disbanded and were waiting, some of them at least, to be enlisted in the Spenish service. This information was conveyed from the earl of Ormond by one Captrin Digby, who found the king at York on his way to Scotland. It must have been then the month of Angust. The hing thereupon, according to Antrim, returned a message by Digby 'signifying his pleasure that all possible endeavours should be used for getting again together those 8,000 men so disbanded, and that an army should immedistaly be raised in Ireland thet should declare for him against the parliament of England, if occasion should be for so doing, and to do what therein was necessary and convenient for his service. Upon receiving this the ling's plessure, he, the lord of Antrim, imparted the design to the lord of Gormanstown and to the lord of Slane, and after to many others in Leinster; and after going into Ulster he communicated the same to many there. But the fools (such was his lordship's expression to us), well liking the business, woold not expect our time or manner for ordering the work; but fell upon it without us and sooner and otherwise than we should have done, taking to themselves and in their own way the managing of the work and so spoiled it.'

In objection to this account it is usual to urge that the earl of Ormond, notwithstanding his unquestioned loyalty to Charles, was far too good a protestant (as witness his conduct in the subsequent negotiations for a treaty with the Irish catholics) to consent to such a toleration of the Roman catholic religion as would endanger the protestant interest in Ireland, and which it is presumed was to be the price of the Irish assistance. This riew, however, appears to rest on a misapprehension of the wishes of the Irish eatholic nobility and gentry. No doubt they desired above all things the free exercise of their religion; bet at the time of their negotistions with the king this idea had not come 80 largely into prominenee as it did a short time aftarwards. What the Irish were especislly anxious to secure was the long-promised Graces. For the nonce their interests were identical with the ling's. From the parliament they had nothing to expect but the absolute suppression of whst religious froedom they then en. joyed. Under the circumstances the substitation of a simple ath of allegiance for that of supremacy, the confirmstion of their titles, and a racit acknowledgment of religious liberty, seemed a boon sufficiently great to draw them to the ling's side. To Ormond, who always deprecated harsh messures against the catholic Irish, this could not be objectionsble. Still Ormond was a protestant, and it was for this reason mainly, I think, that Charles employed the earl of Antrim, a Roman catholic, but, sccording to Strafford, no incompetent jodge in such matters, a man of amall ability and mean militsry akill. This view of the eard of Ormond's complicity in the plot for seiring Dublin castie and 
ousting the government is confirmed by Sir Phelim O'Neil's statement in 1658 to the effect that the earl was represented at the meetings of the conspirators by Colonel John Barry, who was very intimste with him. This statement will be found in Miss Hickson's ' Irish Massacres of 1641,' ii. p. 191. That the Irish believed Ormond to be privy to the scheme is evident from a passage in the 'Aphorismical Discovery,' printed by Mr. Gilbert, i. p. 12, to the effect that he had been sworn as one of the seventy-eight persons who undertook to secure each his town or fort. (Compare Mr. Gardiner's note on p. 7, vol. I of his ' History of England.') On these grounds, then, Antrim's statoment may be accepted as substantislly trae. One clanse in the earl's deposition does not seem to have attracted attention, but which may serve to throw some additional light on the ling's conduct. Antrim, it will be remembered, was commonded to raise an army ' that should declare for the king against the parliament if occasion should be for so doing.' Now it will likewise be remembered that Charles when he sent this message to Captain Digby was at York on his wey to Scotland. The ides immediately before him was to induce the Soots to abandon their alliance with the English parliament. Deprived of their support, he thought himself able, either with or without Bcotch asgistance, to suppress the leaders of the commons at home. It was for this reason that this clause was added in the instructions sent to Antrim. For a moment after his arrival in Scotland the course of events seemed to warrant his expectations. For this reason the conspirators in Ireland Jere not in a houry to precipitate matters. Their dilatoriness, however, did not prove scceptsble to the more ardent Lrish monder O'More and O'Neil, who began to think the plot was to be abandoned. They therefore reverted to their ald soheme, and determining to act by themselves spoiled the affair sccording to the earl of Antrim. By the month of October, however, Charles began to seo that his hopes of Scotch collusion in his design against the English commons were delusive, and he too reverted to his old plan $\rightarrow$ plan originally prompted by Strafford-of conquering England by means of an Irish army. Some time in October, then, he despatched Lord Dillon, who was with him in Scotland and in whom he reposed full confidence, with a message to the Irish conspirators. But again the notification of the ling's pleasure arrived too lete; for by that time the north of Ireland was in a state of open rebellion. All this seems perfectly olear; but it is a very different matter when we try to answer the question-what was the tenor of Iord Dillon's instructions ? Did the king go so far as to give into Lord Dillon's hands or transmit by Bome other means to Sir Phelim O'Neil the following commission?

- Charles, by the Grace of God, King of England, Sootland, France, and Ireland, Defender of the Faith de. to all Catholio subjects within the Fingdom of Ireland, greeting : Know je, that We, for the safoguard and preservation of Our person, have been enforced to make our abode and residence in the hingdom of Bootland for a long season, occasioned by reason of the obstinate and disobedient carriage of the Parliament of England against Us; that hath not only presumed to take upon them the government and disposition of those princely rights and prerogetives, that have justly descended upon Us and Our predecessors, being hings and queens of the said kingdom for many hundred jears past, but sleo have 
possessed themselves of the whole strength of the said lingdom, in appointing governors, commanders, and officers in all places therein, at their own will and pleasure without our consent, whereby We are deprived of Our sovereignty and are left naked without defence. And forasmach as we are in Ourself very sensible that these storms blow aloft and are very likely to be carried by the rehemence of the Protestant party of the kingdom of Ireland, and endanger Our Begal porrer and authority there also; Know je, that We, reposing much care and trast in your duty and obedience, which We have for many years past found, do hereby give unto you fall power and authority to assemble and meet together with all the speed and diligence that basiness of so grest a consequence doth require, and to advise and consalt together by sufficient and discreat numbers at all times, dsys, and places, which you shall in your judgement hold most convenient, and most for the ordering, settling, and effecting the great work [illegible] and directed to you in Our letters, and to use all politic mesns and ways possible to possess yourselves for [illegible] and safety of all the forts, castles, and places of strength and defence within the kingdom, except the places, parsons, and estates of Our loyal and loving sabjects the Scots; also to arrest and seize the goods, estates, and persons of all the English protestants, within the ssid kingdom to Our use. And in your care and speedy performance of this Our will and pleasure We shall rely on your wonted duty and allegiance to Us, which We shall accept and reward in due time. Witness Ourself at Edinburgh this Ist day of Oetober in the seventeenth year of Our reign.'

This is the commission as it stands printed by Miss Hickson ('Irish Massecres,' i. 114), who copied it out of the Armagh rolume of depositions, so that her copy may claim precedence over any other. The commission, it is generally believed, was published by Phelim O'Neil and Roger Maguire on 4 November at Newry, together with the following proclamation: ' Phelim O'Neil, Rory Maguire. To all Catholics of the Roman party, both English and Irish, in the lingdom of Iraland we wish all heppiness, freedom of conscience, and victory over the English heretics, who for a long time have tyrannised over our bodieg and usurped by extortion our estates. Be it hereby made boown wato you all, our friends and countrymen, that the king's most excellent majesty for many grest and urgent conses him therennto moving, imposing trust and confidence in our fidelity, hath signified anto as, by his commission ander the great seal of Scotland, bearing date at Edinbargh, the 18t day of this inst. October 1641, and also by letters under his gign manual, bearing date with the said commission, of divers grest and heinous affronts that the Engliah Protestants, especially the English parliament, have published agrinst his royal prerogative, and also against his Catholic friends, within the kingdom of England, the copy of which commission we here. with send anto you, to be pablished with all speed in all parts of this lingdom that you may be assured of our sufficient warrant and authority therein.' What then are the argaments that may be adduced for and against the gennineness of the commission? Those who believe that Charles did really grant the commission to the Irish rebels appear to base their conclusion principally on the following argoment. The seal affixed is that of Bcotland, and the date of it 1 Oct. 1641. During the troubles in Scotland 
the custody of the broad seal had been committed to the care of the marquis of Hamilton, who had enjoyed the hing's confidence and been entrusted by him with the tagk of managing Scotland and reducing the recalcitrant Scots to submission. Both he and his underkeeper John Hamilton were looked upon as ardent royalists. According to the author of the 'Mystery of Iniquity,' Endymion Porter, who afterwards played a part in the Glamorgan transections, and whose subserviency to Charles is regarded as an assured fact, was also sometimes entrusted with the care of the seal. Now on 30 September it was agreed by the Scotch parliament on the nomination of the king to appoint the earl of Loudon chancellor, and the seal was to be handed over to him on 2 October. On the 1st, then, it was in a state of transition. If, then, the king had determined to grant a commission to the Irish, it is supposed that nothing could have been easier than by working on the loyalty of Hamilton or the underkeeper or Endymion Porter for him to get posses. sion of the seal on that day. Forther, some time between the 1st and the 8th it is known that Lord Dillon was despatched into Ireland nominally to take his seat at the council-board. What, it is asked, more essy than to entrust the commission to him? The coincidence, it is arged, is at lesst extraordinarily suspicious, and this suspicion amounts almost to certainty when we remember the repeated assertions of Sir Phelim O'Neil that he had the king's commission for what he did. Brodie, Reid, Burton, and Miss Hickson are all agreed on this side.

In reply to this argainent we may say that even admitting for facts what are after all only suppositions, it amounts to nothing more than presumptive evidence. We are prepared to admit the coincidence, for which there is another reason. The evidence for the genuineness of the document rests entirely on the supposed loyalty of Hamilton. (See Brodie's note, ii. p. 878, ' History of the British Empire.') Now there is abundant evidence to show that Hamiltan had two or three weeks previous to the appointment of Loudon gone over to Arggle. (See the letter of Sir Patrick Wemyss to the earl of Ormond, dated Edinburgh, 25 Sept., printed in Carte's 'Original Letters.') 'It had gone hard with the Marquis if he had not fallen in with Argyle, who will bring him off. For, believe it, the people here are much incensed against him ; but Argyle and he are sworn to one another, and so think to carry all business.' For Hamilton's treachery Mr. Gardiner's ' History of England, 'x p. 21-2. It was his treachery that led to the quarrel with Lord Ker, and to the event known as the Incident. Of the conduct of Endymion Porter and the underkeeper we know nothing. Further, granting that there was a commission, and that it was sent by Dillon, can we believe that the king would have entrasted the business to Sir Phelim O'Neil and not to the marquis of Antrim, who had conducted the former negotiations? But we may even go farther, and ask is it possible to believe that Charles, notwithstanding all his rash and foolish actions, would ever have so far committed himself ? Miss Hickson. who has been at great pains over this subject, has alleged ('Irish Massacres,' i. p. 116) that the main argument against the genuineness of the commission rests on a statement made by Dean Ker to the effect that Sir Phelim O'Neil at his trial confessed to have cut off the ling's seal from a patent he found in Charlemont castle after its capture, 
which he ordered a Mr. Micheal Harrison (if he, the dean, was not mistaken in the Christian name) and another gentleman (whose name the dean had forgotten) to affr to the forged commission. On the contrary, we are quite willing to pat the dean's testimony out of court, though not convinced by Miss Hickson's argument. It is admitted by all and it is beyond dispate that Sir Phelim O'Neil denied emphatically, both in court and on the sesffold, that he had ever received such a commission from the king. And this the dying statement of a Bomsn catholio, who had nothing to lose and everything to gain by making the admission his judges tried to extor' from him, is sufficiently confirmed by whst we know or can gather regarding the history of this commission.

First : Sir Phelim never allowed any one to examine it so closely as to be able to detect the forged seal. Mr. Michael Harrison, whose deposition Miss Hickson prints (i. 229-238), and who was the chief witness agsinst Sir Phelim, had very good reason to deny ever having put his hand to the forgary, if indeed it whs the same person, who, as Sir Phelim (according to Dean Ker) said, flred the seal to the commission. There were many witnesses ready to swear before the parliamentary commissioners that ' Bir Phelim had often told them he had a commission from the late king for what he acted in the Bebellion ;' but no ane could say that he had seen it, at lesst sufficiently closely to recognise the seal. And it was probsbly owing to this that the first rumour that got abroad and reached the ears of the English parliament was that it was the great seal of England that was attached to it. Becond : after Sir Phelim had effected his purpose of inducing the people to believe that he hed the king's warrant for his rebellion, nothing more wss said sbout the commission. What need, we ask, for all those stipulations between the lords of the Pale and the Ulister Irish respeoting the loyalty of the latter if the former knew that the ling had commanded them to rise? Why those protestations of loyalty on the part of the Ulster Irish themselves if they knew they had a commission which not only exonerated them bat also anthorised their actions? Why that absolute silence regarding a commission, which had it been genuine would have been of the atmost importance to the Irish both st the commencement of the war and at any time during ite progress? To all these queries there is but one answer-the Irish did not possess any such commission as is pretended. Bungiar that he was, Bir Phelim's only objeot was to deceive his countrymen and induce them to rise in rebellion, whereas they needed no such indncement. Thst accomplished, he thought no more about it till he was placed on his trial, and then (let us do justice to his courage, for personally he was brave enough) be atterly denied the charge and unburdened his conscience of the former deception he had practised under the belief that the justness of his cause fully warranted it. And, indeed, so far as the hing was concerned, he was not altogether without justiflcation. The popular belief that Charles was somehow or other mired up in the business was not without foundation. For though we must exculpate Charles from ever having granted this cormmission, yet in the eyes of all impartial critics he must appesr morally culpable of aiding and abetting the rebellion. That the Unster Irish and the catholic Irish generally would altimstely have risen is beyond a doubt; but it was that fatal message brought by Captain Digby 
to the earl of Antrim that inspired them with the courage requisite for the immediate undertsking. What the last messege was that Loord Dillon brought we do not know, only we may feel assured that it was not to conntermand the instructions sent by Digby. Whatever it Fas, it is excoedingly likely that it furnished Sir Phelim and Roger Maguire with the materisls for their forgery. If further proof of the forgery were necesagry, it might be gathered from internal evidence. For, as Mr. Gaxdiner points out (x. 92, n.), Charles would never have spoken of the presbyterians as protestants. One word more. It is commonly supposed that it ras only torards the close of Norember that the existence of the commisaion became known. But it is clear that it existed and was spoken about at the very beginning of the rebellion. There is sbundant evidence in the depositions printed by Miss Hickson to prove this; but whst puts it beyond a doubt is a proclamstion of the lords justices on 30 Oot. against the calumny of the rebels pretending to act by the king's commission (Nalson, ii. 688).

R. DURLoP.

THE BATTIE OP BDGREMI.

Iv the January number of this Review Mr. T. Arnold, in a note on the battle of Edgehill, expresses a wish 'that some competent military man, scquainted with the tactics and means of attack and defence which were in faghion at the time of the Thitty Years' War, would take in hand the campaigns of our English Civil War, and give us accurate and rational acoounts of what was done.' As I have for some years, during time that could be spared from professional duties, been engaged on the task of collecting materials for a military history of the period in question, I venture to put before the readers of Mr. Arnold's note some of the conclusions I have formed regarding this particular action. Following Mr. Arrold's classificstion, I propose to examine, first, the sources of information available; and, secondly, the obscurities, contradictions, and omissions of the authorities.

I. Mr. Arnold ranges the sources of information under five heads, including contemporary accounts, either by eyewitnesses or by those dariving their information st finst hand from such observers, and also those of more modern historians.

It appears to me preferable to consider only the statements mede by contemporaries. It is true that the statements of later friters deserve consideration whan based upon documents not previously arailable, or upon informstion specially acquired; but, judging from internal evidence, so much cannot be said of the accounts of the battle given by any of the four modern writers mentioned by Mr. Amold.

Taking, therefore, only the contemporary anthorities, it will be best to group them into two classes-Royalist and Parliamentarian-and to enter each authority in his own class in what appears to be the order of importance. For brevity's sake the names of the suthorities are given ahartly, and, to facilitate reference to the original documents, indications are also given, in the following lists, to the works in which they are to be 